\title{
BMJ Open Association between previous rheumatoid arthritis and COVID-19 and its severity: a nationwide cohort study in South Korea
}

\author{
Younghee Jung, ${ }^{1}$ Mihye Kwon, ${ }^{2}$ Hyo Geun Choi (D) ${ }^{3}$
}

To cite: Jung Y, Kwon M, Choi HG. Association between previous rheumatoid arthritis and COVID-19 and its severity: a nationwide cohort study in South Korea. BMJ Open 2021;11:e054753. doi:10.1136/ bmjopen-2021-054753

- Prepublication history and additional supplemental material for this paper are available online. To view these files, please visit the journal online (http://dx.doi.org/10.1136/ bmjopen-2021-054753).

Received 29 June 2021 Accepted 24 September 2021

Check for updates

(c) Author(s) (or their employer(s)) 2021. Re-use permitted under CC BY-NC. No commercial re-use. See rights and permissions. Published by BMJ.

${ }^{1}$ Division of Infectious Diseases, Department of Internal Medicine, Hallym University Sacred Heart Hospital, Anyang, Republic of Korea

${ }^{2}$ Division of Rheumatology, Department of Internal Medicine, Konyang University Hospital, Daejeon, Republic of Korea ${ }^{3}$ Department of Otorhinolaryngology-Head \& Neck Surgery, Hallym University Sacred Heart Hospital, Anyang, Republic of Korea

Correspondence to

Dr Hyo Geun Choi;

pupen@naver.com

\section{ABSTRACT}

Objectives The prevalence of rheumatoid arthritis (RA)

among patients with COVID-19 and the association between RA and the outcome of COVID-19 remain unclear. We aimed to compare the prevalence of RA between participants with and without COVID-19; we then analysed the association between the presence of RA and the severity of COVID-19.

Design A cross-sectional study.

Setting Data from a nationwide COVID-19 cohort database by the Korea National Health Insurance Corporation were used.

Participants and interventions A total of 8070 patients with COVID-19 (1 January 2020 through 4 June 2020) were matched with 32280 control participants with regard to age, sex and income. Patients with COVID-19 were confirmed by SARS-CoV-2 PCR and controls were collected from the database. RA was confirmed using the diagnostic code (International Classification of Disease, Tenth Revision) and medication claim codes. Conditional/ unconditional logistic regression was applied to analyse the association between RA and COVID-19.

Primary outcome and secondary outcome Laboratory confirmation of SARS-CoV-2 infection was defined as the primary outcome. The secondary outcome was severe COVID-19 defined as a history of intensive care unit admission, invasive ventilation or death.

Results The prevalence of RA in the COVID-19 (0.4\%, $35 / 8070)$ and control $(0.4 \%, 121 / 32,280)$ groups did not differ $(\mathrm{p}=0.446)$. After adjusting for underlying diseases, no association between RA and COVID-19 was observed (adjusted OR=1.14, 95\% Cl: 0.78 to 1.67) and COVID-19 severity was not associated with RA (adjusted OR=0.62, $95 \% \mathrm{Cl}: 0.14$ to 7.29 ). The overall mortality rate was $2.9 \%$ (237/8070) and RA was not significantly associated with mortality (adjusted OR=1.64, 95\% Cl: 0.33 to 8.15).

Conclusion We did not find an association between the presence of RA and COVID-19. In addition, RA was not associated with the severity of COVID-19.

\section{INTRODUCTION}

The COVID-19 pandemic is ongoing worldwide and risk factors for a poor outcome have been evaluated in several studies. Older age is one of the most important risk factors for severe disease and several comorbidities,
Strengths and limitations of this study

- To our knowledge, this is the first study evaluating the association between rheumatoid arthritis (RA) and COVID-19 in a nationwide cohort.

- The study included patients with RA defined as a criterion validated in a previous study with a high accuracy of over $90 \%$, consistent with the American College of Rheumatology.

- The number of patients with RA was small and thus the differences between groups could not be analysed using a sufficient number of patients.

- The results should be interpreted with caution in countries where different infection control measures have been implemented.

such as cardiovascular disease or diabetes mellitus, have also been associated with a poor prognosis ${ }^{12}$ This pandemic is of particular concern for patients with autoimmune diseases because such individuals are susceptible to various infectious diseases due to both dysregulated immune function and the immunosuppressive agents commonly used which also increase susceptibility to infections and are related to poor outcomes. ${ }^{34}$ Nevertheless, the effects of autoimmune disease on COVID-19 susceptibility and severity remain unclear, with conflicting results to date.

Several case-control studies have reported that the risk of COVID-19 is higher in patients with rheumatic disease than in the general population, ${ }^{56}$ whereas other studies did not find an increased risk. ${ }^{78}$ In terms of prognosis, a recent nationwide study in Denmark reported that patients with inflammatory rheumatic disease are not at higher risk of severe COVID-19 or death than other patients. $^{9}{ }^{10}$ However, a systematic review showed that patients with rheumatic disease were more vulnerable to severe outcomes due to COVID-19, with a 7\% case fatality, which is much higher than that of the general 
Table 1 General characteristics of participants

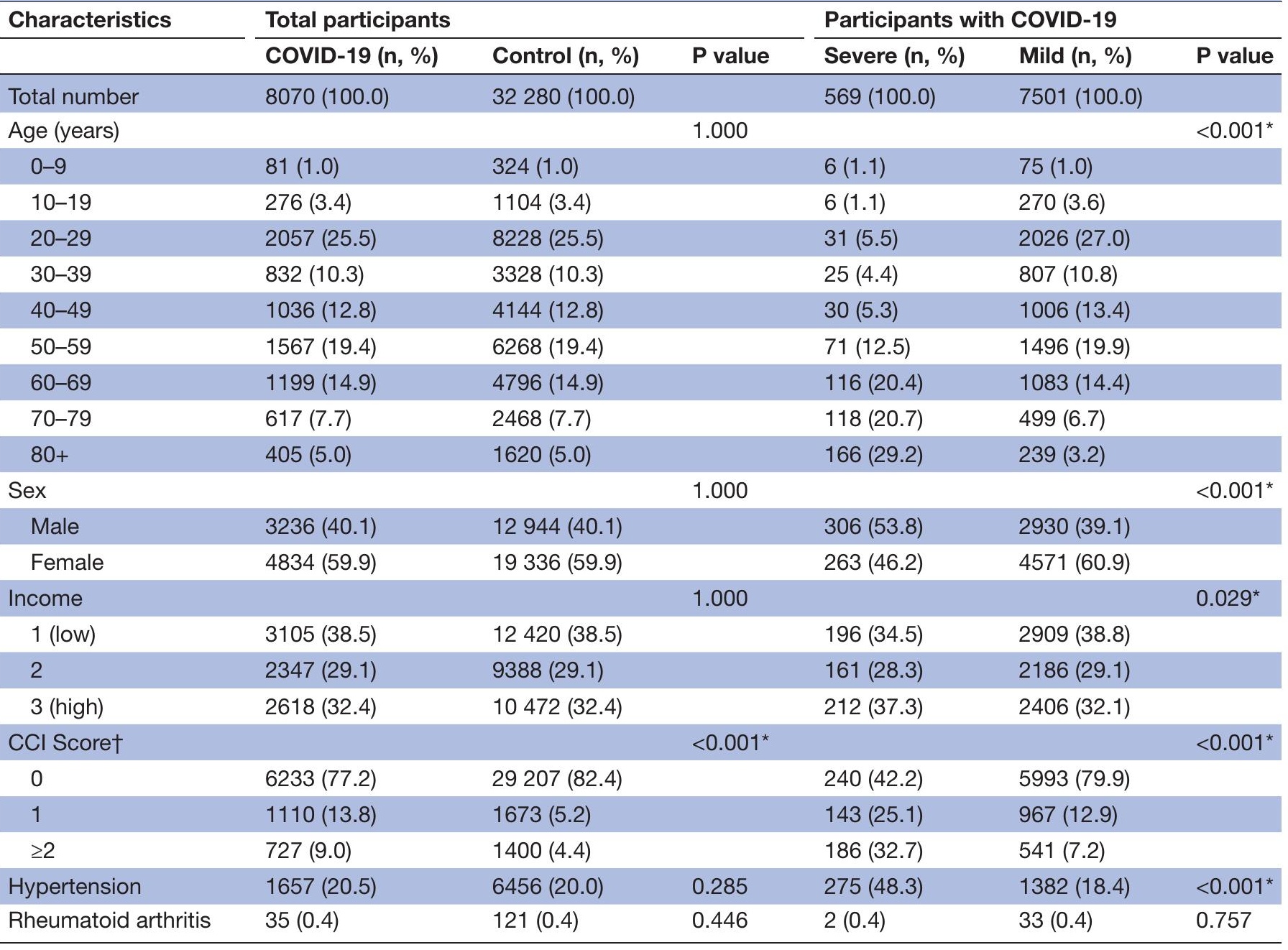

${ }^{*} \chi^{2}$ test or Fisher's exact test. Significance at $p<0.05$.

$+\mathrm{CCl}$ scores were calculated without rheumatic disease.

$\mathrm{CCl}$, Charlson Comorbidity Index.

age, sex, income, CCI Score and hypertension (adjusted $\mathrm{OR}=0.62,95 \% \mathrm{CI}=0.14$ to $2.79, \mathrm{p}=0.553) \quad($ table 3$)$. The additional analysis stratified by age, sex, income, CCI Score and hypertension demonstrated that RA was not associated with disease severity in any subgroup (online supplemental table 2).

The overall mortality rate was $2.9 \%(237 / 8070)$. RA was more common in non-survivors than in survivors
$(2 / 23,0.8 \%$ vs $33 / 7844,0.4 \%)$, but the difference was not significant in either the crude $(\mathrm{p}=0.339)$ or adjusted (adjusted $\mathrm{OR}=1.64,95 \% \mathrm{CI}=0.33$ to $8.15, \mathrm{p}=0.554$ ) analyses (table 4). In addition, RA was not associated with mortality in further subgroup analyses according to age, sex and income (online supplemental table 3). Nevertheless, in the subgroup with a CCI Score of $0 \quad(n=6223)$, RA was significantly more common in non-survivors

\begin{tabular}{|c|c|c|c|c|c|c|}
\hline \multirow[t]{2}{*}{ Characteristics } & \multirow{2}{*}{$\begin{array}{l}\text { COVID-19 } \\
\text { (Exposure/total, \%) }\end{array}$} & \multirow{2}{*}{$\begin{array}{l}\text { Control } \\
\text { (Exposure/total, \%) }\end{array}$} & \multicolumn{4}{|c|}{ ORs $¥(95 \% \mathrm{Cl})$ for COVID-19 } \\
\hline & & & Crude* & $P$ value & Adjusted*,† & $P$ value \\
\hline $\mathrm{RA}$ & $35 / 8070(0.4 \%)$ & $121 / 32280(0.4 \%)$ & $1.16(0.79$ to 1.69$)$ & 0.446 & $1.14(0.78$ to 1.67$)$ & 0.501 \\
\hline Non-RA & $8035 / 8070$ (99.6\%) & 32 159/32 280 (99.6\%) & 1 & & 1 & \\
\hline
\end{tabular}

*Stratified model for age, sex and income.

†The model was adjusted for $\mathrm{CCl}$ scores and hypertension.

$\ddagger$ Conditional logistic regression model. Significance at $p<0.05$.

$\mathrm{CCl}$, Charlson Comorbidity Index. 
Table 3 Crude and adjusted ORs of rheumatoid arthritis (RA) for morbidity in participants with COVID-19

\begin{tabular}{|c|c|c|c|c|c|c|}
\hline \multirow[t]{2}{*}{ Characteristics } & \multirow{2}{*}{$\begin{array}{l}\text { Severe } \\
\text { (Exposure/total, \%) }\end{array}$} & \multirow{2}{*}{$\begin{array}{l}\text { Mild } \\
\text { (Exposure/total, \%) }\end{array}$} & \multicolumn{4}{|c|}{ ORs† $(95 \% \mathrm{Cl})$ for morbidity } \\
\hline & & & Crude & $P$ value & Adjusted* & $P$ value \\
\hline RA & 2/569 (0.4\%) & 33/7501 (0.4\%) & $0.80(0.19$ to 3.34$)$ & 0.758 & 0.62 (0.14 to 2.79$)$ & 0.533 \\
\hline
\end{tabular}

*The model was adjusted for age, sex, income, $\mathrm{CCl}$ scores and hypertension.

†Unconditional logistic regression model, Significance at $\mathrm{p}<0.05$.

$\mathrm{CCl}$, Charlson Comorbidity Index.

$(\mathrm{p}=0.004)$ and the significance was maintained after adjusting for other variables (adjusted $\mathrm{OR}=5.90,95 \%$ $\mathrm{CI}=1.12$ to $31.02, \mathrm{p}=0.036$ ) (online supplemental table 3). In the subgroup analysis of patients without hypertension $(\mathrm{n}=6413)$, RA was associated with mortality after adjusting for other variables (adjusted $\mathrm{OR}=13.29$, 95\% CI=2.26 to 77.97, $\mathrm{p}=0.004$ ).

\section{DISCUSSION}

This nationwide cohort study shows that previous RA is not associated with COVID-19 or its severity. To our knowledge, this is the first study evaluating the association between RA and COVID-19 in a nationwide cohort. Despite concerns regarding an increased risk of COVID-19 in patients with RA and other infectious diseases, we did not observe any association between RA and COVID-19. This is consistent with previous studies. ${ }^{722-25}$ For example, a population-based study conducted in a regional area in Germany compared infection risk in patients with RA with characteristics similar to those of our patients (patients taking DMARDs) with all residents in the area and the authors did not find a difference in infection rate. ${ }^{24}$ Similarly, several regional studies in Italy reported that the incidence of COVID-19 is consistent with that in the general population. ${ }^{232526}$ However, those studies did not adjust for confounding factors and reported only the crude infection rate. In contrast, Parblo $e t a l^{27}$ demonstrated a significantly higher prevalence in patients with rheumatic disease than in the general population, but they analysed only hospitalised patients, so their findings are not applicable to the general population. Systematic reviews have demonstrated a significantly higher infection risk in patients with rheumatic disease than in controls, but most individual studies did not report a significant difference in the risk of infection. ${ }^{1516}$ However, the results of the meta-analyses should be interpreted with caution because of the considerable heterogeneity of the included patients in terms of disease category and COVID-19 diagnostic method. ${ }^{15} 16$ One of the included studies analysed only patients with non-inflammatory arthritis ${ }^{28}$ and other studies included patients with serologically or clinically diagnosed COVID-19. ${ }^{56}$

The low prevalence rate in South Korea might preclude reaching statistical power to detect a significant difference between patients with RA and the general population. Hong Kong, a relatively well-controlled COVID-19 area, has a prevalence rate similar to that of South Korea $(0.014 \%)$, with similar results to ours in a territory-wide study. ${ }^{29}$ In addition, patients with RA might be more cautious regarding COVID-19 because of their chronic illness, with a lower chance of exposure. ${ }^{26}$ This might mask the true susceptibility of patients with RA to COVID19. To evaluate the actual effect of RA on susceptibility to COVID-19, patients with rheumatic disease should be compared with the general population with the same exposure history. One study in China that analysed 42 families found that patients with rheumatic disease were more likely to be infected with COVID-19 than were patients without rheumatic disease (adjusted $\mathrm{OR}=3.32$, $\mathrm{p}=0.023) .^{5}$ This finding suggests higher susceptibility in patients with rheumatic disease but, an adjustment was performed for only age and sex without underlying comorbidities, with no detailed assessment of exposure intensity. ${ }^{5}$

In the present study, RA was not associated with COVID-19 severity or mortality. This finding is in agreement with previous individual case-control studies that showed no differences in severe outcomes, including

\begin{tabular}{|c|c|c|c|c|c|c|}
\hline \multirow[t]{2}{*}{ Characteristics } & \multirow{2}{*}{$\begin{array}{l}\text { Non-survivors } \\
\text { (Exposure/total, \%) }\end{array}$} & \multirow{2}{*}{$\begin{array}{l}\text { Survivors } \\
\text { (Exposure/total, \%) }\end{array}$} & \multicolumn{4}{|c|}{ ORs† $(95 \% \mathrm{Cl})$ for mortality } \\
\hline & & & Crude & P value & Adjusted* & $P$ value \\
\hline RA & 2/237 (0.8\%) & 33/7833 (0.4\%) & 2.01 (0.48 to 8.43$)$ & 0.339 & $\begin{array}{l}1.64(0.33 \text { to } \\
8.15)\end{array}$ & 0.544 \\
\hline Non-RA & 235/237 (99.2\%) & 7800/7833 (99.6\%) & 1 & & 1 & \\
\hline
\end{tabular}

${ }^{*}$ The model was adjusted for age, sex, income, $\mathrm{CCl}$ scores and hypertension.

†Unconditional logistic regression model. Significance at $p<0.05$.

$\mathrm{CCl}$, Charlson Comorbidity Index. 
death, compared with the control population. ${ }^{7} 13142430$ Moreover, two meta-analyses did not find significant differences in severe outcomes between patients with rheumatic disease and the general population. Nationwide cohort studies in Denmark and Hong Kong also reported that the severe outcome was not significantly higher than that of the general population. ${ }^{92}$

In terms of mortality, RA was not associated with death among all patients with COVID-19 in our study, with $2.9 \%$ overall mortality, lower than that in other work. ${ }^{1011} 1431$ This might lead to low statistical power for demonstrating a difference in death. Nonetheless, the largest case-control study with much higher overall mortality (15.6\%) showed that patients with RA did not have higher mortality than patients without RA after adjusting for other variables. ${ }^{14}$ Another study in Demark reported 22\% mortality in the general population (vs $34.0 \%$ in patients with RA), but the difference was not significant. ${ }^{9}$ These findings suggest that the outcome of COVID-19 is strongly influenced by other variables, such as age or other comorbidities, as opposed to RA. ${ }^{15}$ Interestingly, RA was associated with mortality in our subgroup analysis in patients with a CCI Score of 0 (adjusted HR=5.90, $\mathrm{p}=0.036$ ). The patients in this group were younger than 50 years and did not have significant comorbidities except for RA, among which RA can negatively affect mortality. However, the number of deaths was small $(n=2)$ in the group of patients with RA and the clinical implication of this result should be considered carefully. Recently, patients with inflammatory arthritis showed an increased likelihood of testing positive for COVID-19 and severe COVID-19 outcomes inconsistent with our study. ${ }^{32}$ However, that study involved some differences in the inclusion criteria and the definition of severe COVID-19. The researchers included RA as an inflammatory arthritis with other types of arthritis such as psoriatic arthritis and compared patients with and without inflammatory arthritis; in contrast, we only included patients with RA. Furthermore, that study defined any oxygen demand as severe COVID-19. In addition, the study design for selecting study patients was different, where it included only patients who received the COVID-19 test. Our study selected the control patient regardless of the history of COVID-19 testing. These factors might have led to the different compared with our study.

Regarding the effect of medication, systematic reviews have demonstrated that targeted synthetic biologics are associated with a low risk of hospitalisation and death. ${ }^{16}$ Although we did not investigate the impact of specific medications on severity, the results of previous studies suggest that those medications at least do not adversely affect the outcome of COVID-19. If we included patients with RA not using DMARDs or biologics, few patients would be included when considering the diagnostic accuracy of our definition of RA. ${ }^{18}$ Given the low prevalence of COVID-19 in South Korea, demonstrating an influence of specific medications on the prognosis of COVID-19 would be difficult.
Our study has several strengths. First, this is the first nationwide cohort study to investigate the association between RA and both COVID-19 and its severity. Second, exposure and outcome were accurately measured in the present study. Exposure (RA) was defined as a diagnostic code and specific medication claim codes and this definition was validated in a previous study with a high accuracy of over 90\%, consistent with the American College of Rheumatology. ${ }^{18}$ South Korea has not experienced a shortage of diagnostic kits and anyone is able to receive a COVID-19 test, regardless of symptoms, thus reducing the chance of missing cases. Regarding severity, all patients with COVID-19 were registered in the Korea Center for Disease Control and were followed in the hospital or residential treatment centre until recovery or death because self-quarantine was not allowed. Therefore, South Korea has no missing data on COVID-19 outcome. Last, treatment for COVID-19 was free of charge; in other words, the best supportive care was given equally to all patients with RA or controls, decreasing the possibility of the impact of treatment on outcome.

This study also has limitations. First, the number of patients with RA was small because of the strict definition of the disease. According to the inclusion criteria, we did not include patients with RA not using biologics or DMARDs; hence, our results cannot be applied to patients not taking those medications. Second, South Korea maintained strict infection control at the beginning of the pandemic; social distancing and universal mask wearing were expected to be followed nationwide, which exceedingly decreased the chance of contact exposure. This situation might have resulted in an insufficient number of patients for analysing the differences between groups. Our data are reassuring to patients with RA concerning the risk of COVID-19 and its consequences but should be interpreted with caution in countries where different infection control measures have been implemented.

\section{CONCLUSION}

We did not find a higher prevalence of RA in patients with COVID-19 than in control patients. In addition, the presence of RA was not associated with severe COVID-19 or death from COVID-19.

Acknowledgements The authors acknowledge all the healthcare workers involved in the diagnosis and treatment of patients with COVID-19 in South Korea. The authors thank the Korea Disease Control and Prevention Agency, National Medical Center and health information managers in the hospitals for their efforts with regard to collecting the medical records.

Contributors HGC designed the study. HGC and YJ collected data. YJ and MK wrote the manuscript.

Funding This work was supported in part by research grants (NRF-2018R1D1A1A0-2085328; NRF-2021-R1C1C100498611; NRF-2020-R1G1A109988211) from the National Research Foundation (NRF) of Korea.

Competing interests None declared.

Patient consent for publication Not applicable.

Ethics approval The ethics committee of Hallym University (2020-07-022) approved this study. Written informed consent was waived by the Institutional 
Review Board. All analyses adhered to the guidelines and regulations of the Ethics Committee of Hallym University.

Provenance and peer review Not commissioned; externally peer reviewed.

Data availability statement Data are available upon reasonable request.

Supplemental material This content has been supplied by the author(s). It has not been vetted by BMJ Publishing Group Limited (BMJ) and may not have been peer-reviewed. Any opinions or recommendations discussed are solely those of the author(s) and are not endorsed by BMJ. BMJ disclaims all liability and responsibility arising from any reliance placed on the content. Where the content includes any translated material, BMJ does not warrant the accuracy and reliability of the translations (including but not limited to local regulations, clinical guidelines, terminology, drug names and drug dosages), and is not responsible for any error and/or omissions arising from translation and adaptation or otherwise.

Open access This is an open access article distributed in accordance with the Creative Commons Attribution Non Commercial (CC BY-NC 4.0) license, which permits others to distribute, remix, adapt, build upon this work non-commercially, and license their derivative works on different terms, provided the original work is properly cited, appropriate credit is given, any changes made indicated, and the use is non-commercial. See: http://creativecommons.org/licenses/by-nc/4.0/.

ORCID iD

Hyo Geun Choi http://orcid.org/0000-0003-1655-9549

\section{REFERENCES}

1 Wu Z, McGoogan JM. Characteristics of and important lessons from the coronavirus disease 2019 (COVID-19) outbreak in China: summary of a report of 72314 cases from the Chinese center for disease control and prevention. JAMA 2020;323:1239-42.

2 Williamson EJ, Walker AJ, Bhaskaran K, et al. Factors associated with COVID-19-related death using OpenSAFELY. Nature 2020;584:430-6.

3 Listing J, Gerhold K, Zink A. The risk of infections associated with rheumatoid arthritis, with its comorbidity and treatment. Rheumatology 2013;52:53-61.

4 Yang JM, Koh HY, Moon SY, et al. Allergic disorders and susceptibility to and severity of COVID-19: A nationwide cohort study. J Allergy Clin Immunol 2020;146:790-8.

5 Zhong J, Shen G, Yang H, et al. COVID-19 in patients with rheumatic disease in Hubei Province, China: a multicentre retrospective observational study. Lancet Rheumatol 2020;2:e557-64.

6 Benucci M, Damiani A, Giannasi G, et al. Serological tests confirm the low incidence of COVID-19 in chronic rheumatic inflammatory diseases treated with biological DMARD. Ann Rheum Dis 2020. doi:10.1136/annrheumdis-2020-218214. [Epub ahead of print: $06 \mathrm{Ju}$ 2020] (published Online First: 2020/07/08).

7 Salvarani C, Bajocchi G, Mancuso P, et al. Susceptibility and severity of COVID-19 in patients treated with bDMARDS and tsDMARDs: a population-based study. Ann Rheum Dis 2020;79:986.2-8.

8 Favalli EG, Ingegnoli F, Cimaz R, et al. What is the true incidence of COVID-19 in patients with rheumatic diseases? Ann Rheum Dis 2021;80:e18.

9 Cordtz R, Lindhardsen J, Soussi BG, et al. Incidence and severeness of COVID-19 hospitalisation in patients with inflammatory rheumatic disease: a nationwide cohort study from Denmark. Rheumatology 2020. doi:10.1093/rheumatology/keaa897. [Epub ahead of print: 28 Dec 2020].

10 Kjeldsen J, Nielsen J, Ellingsen T, et al. Outcome of COVID-19 in hospitalized patients with chronic inflammatory diseases. A population based national register study in Denmark. J Autoimmun 2021;120:102632.

11 Xu C, Yi Z, Cai R, et al. Clinical outcomes of COVID-19 in patients with rheumatic diseases: a systematic review and meta-analysis of global data. Autoimmun Rev 2021;20:102778.

12 Ye C, Cai S, Shen G, et al. Clinical features of rheumatic patients infected with COVID-19 in Wuhan, China. Ann Rheum Dis 2020;79:1007-13.
13 D'Silva KM, Serling-Boyd N, Wallwork R, et al. Clinical characteristics and outcomes of patients with coronavirus disease 2019 (COVID-19) and rheumatic disease: a comparative cohort study from a US 'hot spot'. Ann Rheum Dis 2020;79:1156-62.

14 Pablos JL, Galindo M, Carmona L, et al. Clinical outcomes of hospitalised patients with COVID-19 and chronic inflammatory and autoimmune rheumatic diseases: a multicentric matched cohort study. Ann Rheum Dis 2020;79:1544-9.

15 Wang Q, Liu J, Shao R, et al. Risk and clinical outcomes of COVID-19 in patients with rheumatic diseases compared with the general population: a systematic review and meta-analysis. Rheumatol Int 2021;41:851-61.

16 Akiyama S, Hamdeh S, Micic D, et al. Prevalence and clinical outcomes of COVID-19 in patients with autoimmune diseases: a systematic review and meta-analysis. Ann Rheum Dis 2021;80:384-91.

17 Sung Y-K, Cho S-K, Choi C-B, et al. Prevalence and incidence of rheumatoid arthritis in South Korea. Rheumatol Int 2013;33:1525-32.

18 Cho S-K, Sung Y-K, Choi C-B, et al. Development of an algorithm for identifying rheumatoid arthritis in the Korean National health insurance claims database. Rheumatol Int 2013;33:2985-92.

19 Lee SW, Ha EK, Yeniova Abdullah Özgür, et al. Severe clinical outcomes of COVID-19 associated with proton pump inhibitors: a nationwide cohort study with propensity score matching. Gut 2021;70:76-84.

20 Lee SW, Yang JM, Moon SY, et al. Association between mental illness and COVID-19 susceptibility and clinical outcomes in South Korea: a nationwide cohort study. Lancet Psychiatry 2020;7:1025-31.

21 Quan H, Li B, Couris CM, et al. Updating and validating the Charlson comorbidity index and score for risk adjustment in hospital discharge Abstracts using data from 6 countries. Am J Epidemiol 2011;173:676-82.

22 Favalli EG, Ingegnoli F, De Lucia O, et al. COVID-19 infection and rheumatoid arthritis: Faraway, so close! Autoimmun Rev 2020;19:102523.

23 Favalli EG, Monti S, Ingegnoli F, et al. Incidence of COVID-19 in patients with rheumatic diseases treated with targeted immunosuppressive drugs: what can we learn from observational data? Arthritis Rheumatol 2020;72:1600-6.

24 Aries P, lking-Konert C. No increased rate of SARS-CoV-2 infection for patients with inflammatory rheumatic diseases compared with the general population in the city of Hamburg (Germany). Ann Rheum Dis 2020. doi:10.1136/annrheumdis-2020-218400. [Epub ahead of print: 07 Aug 2020].

25 Quartuccio L, Valent F, Pasut E, et al. Prevalence of COVID-19 among patients with chronic inflammatory rheumatic diseases treated with biologic agents or small molecules: a population-based study in the first two months of COVID-19 outbreak in Italy. Joint Bone Spine 2020;87:439-43.

26 Zen M, Fuzzi E, Astorri D, et al. SARS-CoV-2 infection in patients with autoimmune rheumatic diseases in northeast Italy: a crosssectional study on 916 patients. J Autoimmun 2020;112:102502.

27 Pablos JL, Abasolo L, Alvaro-Gracia JM, et al. Prevalence of hospital PCR-confirmed COVID-19 cases in patients with chronic inflammatory and autoimmune rheumatic diseases. Ann Rheum Dis 2020;79:1170-3.

28 Blanch-Rubió J, Soldevila-Domenech N, Tío L, et al. Influence of anti-osteoporosis treatments on the incidence of COVID-19 in patients with non-inflammatory rheumatic conditions. Aging 2020;12:19923-37.

29 So H, Mak JW-Y, So J, et al. Incidence and clinical course of COVID-19 in patients with rheumatologic diseases: a populationbased study. Semin Arthritis Rheum 2020;50:885-9.

30 Mena Vázquez N, Manrique-Arija S, Cabezudo-García P, et al. Incidence and case fatality rate of COVID-19 in patients with inflammatory articular diseases. Int J Clin Pract 2021;75:e13707.

31 Gianfrancesco M, Hyrich KL, Al-Adely S, et al. Characteristics associated with hospitalisation for COVID-19 in people with rheumatic disease: data from the COVID-19 global rheumatology alliance physician-reported registry. Ann Rheum Dis 2020;79:859-66.

32 Shin YH, Shin JI, Moon SY, et al. Autoimmune inflammatory rheumatic diseases and COVID-19 outcomes in South Korea: a nationwide cohort study. Lancet Rheumatol 2021;3:e698-706. 
Review Board. All analyses adhered to the guidelines and regulations of the Ethics Committee of Hallym University.

Provenance and peer review Not commissioned; externally peer reviewed.

Data availability statement Data are available upon reasonable request.

Supplemental material This content has been supplied by the author(s). It has not been vetted by BMJ Publishing Group Limited (BMJ) and may not have been peer-reviewed. Any opinions or recommendations discussed are solely those of the author(s) and are not endorsed by BMJ. BMJ disclaims all liability and responsibility arising from any reliance placed on the content. Where the content includes any translated material, BMJ does not warrant the accuracy and reliability of the translations (including but not limited to local regulations, clinical guidelines, terminology, drug names and drug dosages), and is not responsible for any error and/or omissions arising from translation and adaptation or otherwise.

Open access This is an open access article distributed in accordance with the Creative Commons Attribution Non Commercial (CC BY-NC 4.0) license, which permits others to distribute, remix, adapt, build upon this work non-commercially, and license their derivative works on different terms, provided the original work is properly cited, appropriate credit is given, any changes made indicated, and the use is non-commercial. See: http://creativecommons.org/licenses/by-nc/4.0/.

ORCID iD

Hyo Geun Choi http://orcid.org/0000-0003-1655-9549

\section{REFERENCES}

1 Wu Z, McGoogan JM. Characteristics of and important lessons from the coronavirus disease 2019 (COVID-19) outbreak in China: summary of a report of 72314 cases from the Chinese center for disease control and prevention. JAMA 2020;323:1239-42.

2 Williamson EJ, Walker AJ, Bhaskaran K, et al. Factors associated with COVID-19-related death using OpenSAFELY. Nature 2020;584:430-6.

3 Listing J, Gerhold K, Zink A. The risk of infections associated with rheumatoid arthritis, with its comorbidity and treatment. Rheumatology 2013;52:53-61.

4 Yang JM, Koh HY, Moon SY, et al. Allergic disorders and susceptibility to and severity of COVID-19: A nationwide cohort study. J Allergy Clin Immunol 2020;146:790-8.

5 Zhong J, Shen G, Yang H, et al. COVID-19 in patients with rheumatic disease in Hubei Province, China: a multicentre retrospective observational study. Lancet Rheumatol 2020;2:e557-64.

6 Benucci M, Damiani A, Giannasi G, et al. Serological tests confirm the low incidence of COVID-19 in chronic rheumatic inflammatory diseases treated with biological DMARD. Ann Rheum Dis 2020. doi:10.1136/annrheumdis-2020-218214. [Epub ahead of print: $06 \mathrm{Ju}$ 2020] (published Online First: 2020/07/08).

7 Salvarani C, Bajocchi G, Mancuso P, et al. Susceptibility and severity of COVID-19 in patients treated with bDMARDS and tsDMARDs: a population-based study. Ann Rheum Dis 2020;79:986.2-8.

8 Favalli EG, Ingegnoli F, Cimaz R, et al. What is the true incidence of COVID-19 in patients with rheumatic diseases? Ann Rheum Dis 2021;80:e18.

9 Cordtz R, Lindhardsen J, Soussi BG, et al. Incidence and severeness of COVID-19 hospitalisation in patients with inflammatory rheumatic disease: a nationwide cohort study from Denmark. Rheumatology 2020. doi:10.1093/rheumatology/keaa897. [Epub ahead of print: 28 Dec 2020].

10 Kjeldsen J, Nielsen J, Ellingsen T, et al. Outcome of COVID-19 in hospitalized patients with chronic inflammatory diseases. A population based national register study in Denmark. J Autoimmun 2021;120:102632.

11 Xu C, Yi Z, Cai R, et al. Clinical outcomes of COVID-19 in patients with rheumatic diseases: a systematic review and meta-analysis of global data. Autoimmun Rev 2021;20:102778.

12 Ye C, Cai S, Shen G, et al. Clinical features of rheumatic patients infected with COVID-19 in Wuhan, China. Ann Rheum Dis 2020;79:1007-13.
13 D'Silva KM, Serling-Boyd N, Wallwork R, et al. Clinical characteristics and outcomes of patients with coronavirus disease 2019 (COVID-19) and rheumatic disease: a comparative cohort study from a US 'hot spot'. Ann Rheum Dis 2020;79:1156-62.

14 Pablos JL, Galindo M, Carmona L, et al. Clinical outcomes of hospitalised patients with COVID-19 and chronic inflammatory and autoimmune rheumatic diseases: a multicentric matched cohort study. Ann Rheum Dis 2020;79:1544-9.

15 Wang Q, Liu J, Shao R, et al. Risk and clinical outcomes of COVID-19 in patients with rheumatic diseases compared with the general population: a systematic review and meta-analysis. Rheumatol Int 2021;41:851-61.

16 Akiyama S, Hamdeh S, Micic D, et al. Prevalence and clinical outcomes of COVID-19 in patients with autoimmune diseases: a systematic review and meta-analysis. Ann Rheum Dis 2021;80:384-91.

17 Sung Y-K, Cho S-K, Choi C-B, et al. Prevalence and incidence of rheumatoid arthritis in South Korea. Rheumatol Int 2013;33:1525-32.

18 Cho S-K, Sung Y-K, Choi C-B, et al. Development of an algorithm for identifying rheumatoid arthritis in the Korean National health insurance claims database. Rheumatol Int 2013;33:2985-92.

19 Lee SW, Ha EK, Yeniova Abdullah Özgür, et al. Severe clinical outcomes of COVID-19 associated with proton pump inhibitors: a nationwide cohort study with propensity score matching. Gut 2021;70:76-84.

20 Lee SW, Yang JM, Moon SY, et al. Association between mental illness and COVID-19 susceptibility and clinical outcomes in South Korea: a nationwide cohort study. Lancet Psychiatry 2020;7:1025-31.

21 Quan H, Li B, Couris CM, et al. Updating and validating the Charlson comorbidity index and score for risk adjustment in hospital discharge Abstracts using data from 6 countries. Am J Epidemiol 2011;173:676-82.

22 Favalli EG, Ingegnoli F, De Lucia O, et al. COVID-19 infection and rheumatoid arthritis: Faraway, so close! Autoimmun Rev 2020;19:102523.

23 Favalli EG, Monti S, Ingegnoli F, et al. Incidence of COVID-19 in patients with rheumatic diseases treated with targeted immunosuppressive drugs: what can we learn from observational data? Arthritis Rheumatol 2020;72:1600-6.

24 Aries P, lking-Konert C. No increased rate of SARS-CoV-2 infection for patients with inflammatory rheumatic diseases compared with the general population in the city of Hamburg (Germany). Ann Rheum Dis 2020. doi:10.1136/annrheumdis-2020-218400. [Epub ahead of print: 07 Aug 2020].

25 Quartuccio L, Valent F, Pasut E, et al. Prevalence of COVID-19 among patients with chronic inflammatory rheumatic diseases treated with biologic agents or small molecules: a population-based study in the first two months of COVID-19 outbreak in Italy. Joint Bone Spine 2020;87:439-43.

26 Zen M, Fuzzi E, Astorri D, et al. SARS-CoV-2 infection in patients with autoimmune rheumatic diseases in northeast Italy: a crosssectional study on 916 patients. J Autoimmun 2020;112:102502.

27 Pablos JL, Abasolo L, Alvaro-Gracia JM, et al. Prevalence of hospital PCR-confirmed COVID-19 cases in patients with chronic inflammatory and autoimmune rheumatic diseases. Ann Rheum Dis 2020;79:1170-3.

28 Blanch-Rubió J, Soldevila-Domenech N, Tío L, et al. Influence of anti-osteoporosis treatments on the incidence of COVID-19 in patients with non-inflammatory rheumatic conditions. Aging 2020;12:19923-37.

29 So H, Mak JW-Y, So J, et al. Incidence and clinical course of COVID-19 in patients with rheumatologic diseases: a populationbased study. Semin Arthritis Rheum 2020;50:885-9.

30 Mena Vázquez N, Manrique-Arija S, Cabezudo-García P, et al. Incidence and case fatality rate of COVID-19 in patients with inflammatory articular diseases. Int J Clin Pract 2021;75:e13707.

31 Gianfrancesco M, Hyrich KL, Al-Adely S, et al. Characteristics associated with hospitalisation for COVID-19 in people with rheumatic disease: data from the COVID-19 global rheumatology alliance physician-reported registry. Ann Rheum Dis 2020;79:859-66.

32 Shin YH, Shin JI, Moon SY, et al. Autoimmune inflammatory rheumatic diseases and COVID-19 outcomes in South Korea: a nationwide cohort study. Lancet Rheumatol 2021;3:e698-706. 
Review Board. All analyses adhered to the guidelines and regulations of the Ethics Committee of Hallym University.

Provenance and peer review Not commissioned; externally peer reviewed.

Data availability statement Data are available upon reasonable request.

Supplemental material This content has been supplied by the author(s). It has not been vetted by BMJ Publishing Group Limited (BMJ) and may not have been peer-reviewed. Any opinions or recommendations discussed are solely those of the author(s) and are not endorsed by BMJ. BMJ disclaims all liability and responsibility arising from any reliance placed on the content. Where the content includes any translated material, BMJ does not warrant the accuracy and reliability of the translations (including but not limited to local regulations, clinical guidelines, terminology, drug names and drug dosages), and is not responsible for any error and/or omissions arising from translation and adaptation or otherwise.

Open access This is an open access article distributed in accordance with the Creative Commons Attribution Non Commercial (CC BY-NC 4.0) license, which permits others to distribute, remix, adapt, build upon this work non-commercially, and license their derivative works on different terms, provided the original work is properly cited, appropriate credit is given, any changes made indicated, and the use is non-commercial. See: http://creativecommons.org/licenses/by-nc/4.0/.

ORCID iD

Hyo Geun Choi http://orcid.org/0000-0003-1655-9549

\section{REFERENCES}

1 Wu Z, McGoogan JM. Characteristics of and important lessons from the coronavirus disease 2019 (COVID-19) outbreak in China: summary of a report of 72314 cases from the Chinese center for disease control and prevention. JAMA 2020;323:1239-42.

2 Williamson EJ, Walker AJ, Bhaskaran K, et al. Factors associated with COVID-19-related death using OpenSAFELY. Nature 2020;584:430-6.

3 Listing J, Gerhold K, Zink A. The risk of infections associated with rheumatoid arthritis, with its comorbidity and treatment. Rheumatology 2013;52:53-61.

4 Yang JM, Koh HY, Moon SY, et al. Allergic disorders and susceptibility to and severity of COVID-19: A nationwide cohort study. J Allergy Clin Immunol 2020;146:790-8.

5 Zhong J, Shen G, Yang H, et al. COVID-19 in patients with rheumatic disease in Hubei Province, China: a multicentre retrospective observational study. Lancet Rheumatol 2020;2:e557-64.

6 Benucci M, Damiani A, Giannasi G, et al. Serological tests confirm the low incidence of COVID-19 in chronic rheumatic inflammatory diseases treated with biological DMARD. Ann Rheum Dis 2020. doi:10.1136/annrheumdis-2020-218214. [Epub ahead of print: $06 \mathrm{Ju}$ 2020] (published Online First: 2020/07/08).

7 Salvarani C, Bajocchi G, Mancuso P, et al. Susceptibility and severity of COVID-19 in patients treated with bDMARDS and tsDMARDs: a population-based study. Ann Rheum Dis 2020;79:986.2-8.

8 Favalli EG, Ingegnoli F, Cimaz R, et al. What is the true incidence of COVID-19 in patients with rheumatic diseases? Ann Rheum Dis 2021;80:e18.

9 Cordtz R, Lindhardsen J, Soussi BG, et al. Incidence and severeness of COVID-19 hospitalisation in patients with inflammatory rheumatic disease: a nationwide cohort study from Denmark. Rheumatology 2020. doi:10.1093/rheumatology/keaa897. [Epub ahead of print: 28 Dec 2020].

10 Kjeldsen J, Nielsen J, Ellingsen T, et al. Outcome of COVID-19 in hospitalized patients with chronic inflammatory diseases. A population based national register study in Denmark. J Autoimmun 2021;120:102632.

11 Xu C, Yi Z, Cai R, et al. Clinical outcomes of COVID-19 in patients with rheumatic diseases: a systematic review and meta-analysis of global data. Autoimmun Rev 2021;20:102778.

12 Ye C, Cai S, Shen G, et al. Clinical features of rheumatic patients infected with COVID-19 in Wuhan, China. Ann Rheum Dis 2020;79:1007-13.
13 D'Silva KM, Serling-Boyd N, Wallwork R, et al. Clinical characteristics and outcomes of patients with coronavirus disease 2019 (COVID-19) and rheumatic disease: a comparative cohort study from a US 'hot spot'. Ann Rheum Dis 2020;79:1156-62.

14 Pablos JL, Galindo M, Carmona L, et al. Clinical outcomes of hospitalised patients with COVID-19 and chronic inflammatory and autoimmune rheumatic diseases: a multicentric matched cohort study. Ann Rheum Dis 2020;79:1544-9.

15 Wang Q, Liu J, Shao R, et al. Risk and clinical outcomes of COVID-19 in patients with rheumatic diseases compared with the general population: a systematic review and meta-analysis. Rheumatol Int 2021;41:851-61.

16 Akiyama S, Hamdeh S, Micic D, et al. Prevalence and clinical outcomes of COVID-19 in patients with autoimmune diseases: a systematic review and meta-analysis. Ann Rheum Dis 2021;80:384-91.

17 Sung Y-K, Cho S-K, Choi C-B, et al. Prevalence and incidence of rheumatoid arthritis in South Korea. Rheumatol Int 2013;33:1525-32.

18 Cho S-K, Sung Y-K, Choi C-B, et al. Development of an algorithm for identifying rheumatoid arthritis in the Korean National health insurance claims database. Rheumatol Int 2013;33:2985-92.

19 Lee SW, Ha EK, Yeniova Abdullah Özgür, et al. Severe clinical outcomes of COVID-19 associated with proton pump inhibitors: a nationwide cohort study with propensity score matching. Gut 2021;70:76-84.

20 Lee SW, Yang JM, Moon SY, et al. Association between mental illness and COVID-19 susceptibility and clinical outcomes in South Korea: a nationwide cohort study. Lancet Psychiatry 2020;7:1025-31.

21 Quan H, Li B, Couris CM, et al. Updating and validating the Charlson comorbidity index and score for risk adjustment in hospital discharge Abstracts using data from 6 countries. Am J Epidemiol 2011;173:676-82.

22 Favalli EG, Ingegnoli F, De Lucia O, et al. COVID-19 infection and rheumatoid arthritis: Faraway, so close! Autoimmun Rev 2020;19:102523.

23 Favalli EG, Monti S, Ingegnoli F, et al. Incidence of COVID-19 in patients with rheumatic diseases treated with targeted immunosuppressive drugs: what can we learn from observational data? Arthritis Rheumatol 2020;72:1600-6.

24 Aries P, lking-Konert C. No increased rate of SARS-CoV-2 infection for patients with inflammatory rheumatic diseases compared with the general population in the city of Hamburg (Germany). Ann Rheum Dis 2020. doi:10.1136/annrheumdis-2020-218400. [Epub ahead of print: 07 Aug 2020].

25 Quartuccio L, Valent F, Pasut E, et al. Prevalence of COVID-19 among patients with chronic inflammatory rheumatic diseases treated with biologic agents or small molecules: a population-based study in the first two months of COVID-19 outbreak in Italy. Joint Bone Spine 2020;87:439-43.

26 Zen M, Fuzzi E, Astorri D, et al. SARS-CoV-2 infection in patients with autoimmune rheumatic diseases in northeast Italy: a crosssectional study on 916 patients. J Autoimmun 2020;112:102502.

27 Pablos JL, Abasolo L, Alvaro-Gracia JM, et al. Prevalence of hospital PCR-confirmed COVID-19 cases in patients with chronic inflammatory and autoimmune rheumatic diseases. Ann Rheum Dis 2020;79:1170-3.

28 Blanch-Rubió J, Soldevila-Domenech N, Tío L, et al. Influence of anti-osteoporosis treatments on the incidence of COVID-19 in patients with non-inflammatory rheumatic conditions. Aging 2020;12:19923-37.

29 So H, Mak JW-Y, So J, et al. Incidence and clinical course of COVID-19 in patients with rheumatologic diseases: a populationbased study. Semin Arthritis Rheum 2020;50:885-9.

30 Mena Vázquez N, Manrique-Arija S, Cabezudo-García P, et al. Incidence and case fatality rate of COVID-19 in patients with inflammatory articular diseases. Int J Clin Pract 2021;75:e13707.

31 Gianfrancesco M, Hyrich KL, Al-Adely S, et al. Characteristics associated with hospitalisation for COVID-19 in people with rheumatic disease: data from the COVID-19 global rheumatology alliance physician-reported registry. Ann Rheum Dis 2020;79:859-66.

32 Shin YH, Shin JI, Moon SY, et al. Autoimmune inflammatory rheumatic diseases and COVID-19 outcomes in South Korea: a nationwide cohort study. Lancet Rheumatol 2021;3:e698-706. 